\title{
Merging diaries and GPS records: The method of data collection for spatio-temporal research
}

\author{
Martin ŠVEDA a*, Michala MADAJOVÁ a
}

\begin{abstract}
The results of a 'proof-of-concept' study that examined a new opportunity for using GPS technology in activity surveys are presented in this article. The aim is to demonstrate the method of collection and processing of individual time-space data via the dual records of a time-space diary and the GPS locator. The GPS technology here is not treated as a substitute for the traditional method of diaries; rather, the paper concentrates on the potential existing in a combination of these two techniques. The time-geographical approach and the corresponding methodology are used in order to assess the complexities of an individual's everyday life, and to capture the spectrum of human activities in a data frame applicable to different analyses in behavioural, social and transportation research. This method not only improves the quality and robustness of spatio-temporal data, but also reduces under-reporting and the burdens on the respondents.
\end{abstract}

Key words: time geography, GPS, time-space diary, survey method development

\section{Introduction}

The necessity to capture an individual's behaviour in time and in space is a natural and inherent effort of geographical studies. The recording and analysis of varied human activities and their interactions in an integrated time-space environment is limited, however, by the actual capacities of the traditional tools for the collection and processing of individual records. One of the approaches facilitating tracking of an individual's activities in the complex of social and spatial interaction is time geography. This sub-discipline of Geography with a distinct multidisciplinary character, established itself in the field of geographical research in the 1960s and since then it has produced some successful approaches, providing a systematic theoretical and methodological frame for the analysis of human activities (Carlstein et al., 1978; Hägerstrand, 1970; Lenntorp, 1976; Pred, 1981). Time geography enabled a better comprehension of an individual's spatial and temporal behavioural patterns and the limitations that restrict them (place of work, transport options, administrative barriers, etc.).

In spite of offering such a conceptual apparatus, time geography did not avoid criticism for its unrealistic assumptions or scarce interest in people's individual motivations and social conditions (Hallin, 1991). The response to this criticism has drawn attention to everyday life, where the richness and variety of life styles and the formation of adaptation strategies prevailed over the exact description of spatial mobility (for example, Pratt, 1996; Jarvis, 2005; Novák and Temelová, 2012). On the other hand, researchers who refused to abandon the effort to gather an exact spatial record of individual behaviours, turned to Geographical Information Systems (GIS). At the outset, however, an individual's behaviour modelling in time-space was limited. Researchers worked exclusively with physical space and various simplifying assumptions were adopted. For instance, regular distributions of opportunities in space and a uniform speed were considered. Although the theory concentrated on individuals, the applied part was often based on aggregated territories (Kwan, 2000). But GIS has compensated for many of the limitations of traditional time-space research methods, enabling the capture of activities and an individual's interactions as "processes", anchored in time and space, as the results of interactions of a number of factors.

At the beginning of the 1990s, Miller (1991) had already implemented the concept of a space-time prism into GIS. He tried to mitigate the assumption of a regular speed in the physical environment by the approach of a discrete net representation of time-space. This method was later used by several authors to derive the potential path area of individuals in the research on individual accessibility under the effect of time-spatial constraints (Kwan and Hong, 1998; Miller and Bridwell, 2009; Miller and Wu, 2000; Weber and Kwan, 2002). While some authors dwelled on the analysis of an individual's everyday activities via simple time- and space- queries (Ritsema et al., 2005; Shaw and Wang, 2000), an effort emerged to include the elements of individual cognitive maps associated with spatial behaviours into GIS models, which may contribute to a more realistic dimension of the individual's subjective environment to the theoretical and analytical bases of spatial analysis (Golledge et al., 1994; Kwan, 1998). The results of these analyses, however, were limited by insufficient analytical tools for realistic representations of the environment (Kwan, 2004; Spek et al., 2009), and the lack of detailed individual spatiotemporal data, as well as limited analytical processing due to a 'missing' computing algorithm (Miller, 2005).

The last two decades have brought about a distinct quality improvement in the field of computer technology and software applicable for the collection, processing, analysis and visualisation of large volumes of data. Post-modern society, globalisation, the onset and continuous progress of informatisation, the development of communication technologies (ICT) and adoption of these technologies by the public at large, also changed the relationships between space and time, and contributed to new incentives for human lives. Phenomena, such as 'virtual mobility' and

\footnotetext{
${ }^{a}$ Geografický ústav SAV, Štefánikova 49, 814 73, Bratislava; Slovakia; (*corresponding author: M. Šveda, e-mail: mato.sveda@gmail.com)
} 
the 'fragmentation of daily activities', require approaches which concentrate on individuals and are able to analyse their varied activities and interactions in one integrated time-space environment. GIS is an appropriate tool for the processing and interpretation of such comprehensive data. Applications of GIS were considerably enriched by the development of ICT, and their position in spatio-temporal research has been strengthened by new techniques, which make it possible to track individual movements.

Location-aware technologies, such as the global positioning system (GPS) and radio-location methods based on wireless communication systems, allow measurement of basic time- geographic entities and relations at spatiotemporal resolutions hardly imaginable during time geography's genesis in the mid-20 $0^{\text {th }}$ century (Miller, 2005, p. 18). A key role in such an innovation is played by GPS technology, which has become an indispensable part of peoples' daily lives and a fundamental tool for spatial studies. Time geography has acquired powerful hardware and software tools to process large amounts of data with high resolution of spatial records. Attempts to develop new GIS tools and additional modules are emerging (Buliung, Kanaroglou, 2006; Chen et al., 2011; Shaw et al., 2008; Yu and Shaw, 2008). Current post-modern society brings to the fore fundamental questions for further development of time geography (Hallin, 1991; Kwan and Lee, 2003; Lenntorp, 1999), as well as the need for a transformation of its conceptual and methodological framework (Madajová and Šveda, 2013).

The objective of this paper is to present a particular framework for spatio-temporal research of human behaviours by improving traditional data collection methods in time geography - diary surveys - to include GPS-data collection. Previous research comparing diary-reported to GPS-recorded surveys have generally considered the GPS data to be a powerful tool for time-space research (see Bricka et al., 2012, for discussion). GPS units themselves, however, are not fail-proof and they cannot provide all the necessary data for behavioural research. By merging surveyreported and GPS-reported data collection records into one framework, we aim to provide "true" spatial trajectories, and to reduce trip and activity under-reporting. Individual spatial data have a high scientific potential and have acquired considerable importance, especially in diverse social and transport studies, but their utilization in human (behavioural) geography is rare. Although both data sources are relatively frequently used in time-space studies, we can find only a few examples of their combined use.

Ohmori et al. (2006) presented the development of a GPS-equipped PDA-based activity diary survey system. By comparing the activity data collected by the PDA/GPS instrument with data from a conventional time-space diary survey, it was found that the former method was useful in reducing the time lag in data entry. As well, it was shown that both the number of activities and total activity time recorded were longer in the paper-based survey, particularly for in-home activities (Asakura and Hato, 2009).

Millward and Spinney (2011) combined diary records and precise GPS tracking in the Halifax STAR (SpaceTime Activity Research) survey. Respondents kept track of all the places they visited by carrying a GPS-logger and writing travel activity in a log throughout a 48-hour period. This innovative survey of both time use and travel activity merits the designation of one of the largest GPS samples, within the context of a household travel survey project, undertaken to date. Unfortunately, it is not clear how the data from diary and GPS data were processed, and what challenges and difficulties were encountered in the development of the methodology.

Since there has been a methodological gap in the context of dual diary-GPS surveys, by casting light on this method we can evaluate its usefulness in behavioural research. Using recently collected GPS data from a medium-scale survey ( $\mathrm{n}=60$ individuals), this article attempts to verify the applicability of the method based on a dual record using the time-space diaries and a GPS-logger. The first part the article briefly presents both data sources. Subsequently, a detailed workflow of data synchronization is presented. The article concludes by comparing this method with two alternative ways of time-space tracking.

\section{Merging time-space diaries and GPS records}

Time-space diaries (budgets) represent the traditional method of individual data collection about the everyday activities of a population, and appear with modifications not only in geographical research but also in sociology, psychology and anthropology. Spatial location by GPS is a comparatively frequent form of records in transportation studies, but its application in behavioural or sociological research is rather rare. These tools will be briefly presented in order to introduce the methodological procedures used here.

\subsection{Time-space diaries}

The time-space diary is the traditional tool used in order to identify human activities in space and time. It is a systematic record of an individual's time use and a fundamental tool for the study of the character, duration, sequence, frequency, and the location of human activities (Ira, 2001). This (originally) sociological method is used for tracking phenomena in an individual's life in certain intervals over a certain period, normally over one day or a week. The time-space forms are, as a rule, filled in by the individuals themselves and at certain intervals (after minutes or hours) from the beginning of the particular period, putting down the kind of activity carried out at a given moment and place (geographical feature); whether they carried out the activity alone or in the company/ interaction with someone else (sociological feature). The way they got to the place of the given activity reflects the transportation aspect, which, apart from the identification of means of transport, also contains questions about any means of communication used by the individual during the day (telephone, e-mail, chat, etc.).

Time geography research concentrates first of all on the activities and the time they required, such that the location of activities is often generalised. On the contrary, transportation studies focus on paths in space and the activities themselves, which leads to the use of the paths, such that activities are given less attention (see Bose and Sharp, 2005; Harvey, 2003). These two different views are related to two basic types of time-space diaries: i) activity diaries; and ii) trip diaries. Travelling is one of the activities in the first type, while in the second type activities are partially included as a purpose of the given trip (trip to work, shop or school). Harvey (2003) studies the construction of the two types of diary in detail and discusses their pros and cons. He points out the deficient spatiality of the two approaches and the need to connect the types of diaries in order to obtain the most detailed data possible. Although the time-space diaries bring unique individual records, the spatial dimension is limited 
and its verifiability (reliability) is problematic. In other words, this procedure is posited on the respondent's active collaboration - a requirement that undoubtedly affects the quality of the data gathered (Shoval and Isaacson, 2006). As a matter of fact, respondents may report incorrect time and spatial coordinates of activities or they may leave out some activities. The traditional record does not explicitly show the character of trajectories and does not allow for anchoring the stations in particular spatial coordinates.

The traditional form of time-space diary is also applied in behavioural research in Slovakia and the Czech Republic, both in rural (Ira, 1986) and urban settings (Drgoňa et al., 1994; Ira, 2000; Klapka and Roubalíková, 2010; Pospíšilová and Ouředníček, 2011). Additionally, Osman (2010), who dealt with the specific features of time-spatial behaviour of immobile persons, Mulíček et al. (2010), who researched the transformation of the post-industrial town in terms of its time organisation, and Novák and Sýkora (2007), who analysed time-spatial behavioural patterns of suburban migrants, based their studies on time-geographical concepts. As well, Temelová and Novák (2011) investigated the everyday manifestation of increasing cultural and social diversity and the variability of lifestyles in the transforming centre of Prague, and Temelová et al. (2011) made use of timegeographical tools in the analysis of adaptation strategies of populations living in the periphery.

\subsection{The Global Positioning System (GPS) in spatio-temporal research}

Applications of GPS in research on a population's timespatial behaviour are ever more frequent because of new technologies which make possible the tracking of individual movements in space. The Global Positioning System is the satellite system, formerly used only for military purposes, which establishes position and time on the Earth's surface. When the ban on use in the civil sphere was rescinded in 2000, this technology experienced a dramatic development although the actual boom has occurred only in the last decade with the increasing accessibility of GPS receivers. They have become the everyday companions of people navigation in cars, devices for sport and leisure, or as a part of mobile telephones and personal computers (PDAs), where they assess a position regarding the particular requests of a user. At the beginning, GPS devices were used mainly in transportation surveys (Murakami and Wagner, 1999; Wolf et al., 2000) to capture ways of transport (via in-vehicle GPS systems). Understanding the regularity and the variability of individual travel behaviours over time has been one of the key issues in travel behaviour research for more than two decades (Draijer et al., 2000; Jong and Mensonides, 2003; Giaimo et al., 2009; Krygsman and Nel, 2009). Recently, such positioning technologies offer a real opportunity for innovative research approaches. The feasibility of integrating GPS technologies and behaviour surveys has already been demonstrated in numerous experiments, including a real-time interactive activity diary (e.g. Ohmori et al., 2006), or passive monitoring and automatic trip data processing, as well as hybrid approaches combining passive monitoring and prompted recall interviews (e.g. Auld et al., 2009).

The current technologies of GPS route recording possess characteristics which make time-space research more efficient. They are:

- a high spatial and temporal accuracy;

- a capacity to capture movement in actual time;
- a capacity to record great volumes of data;

- an option to acquire automatically some data concerning an individual's activity and movement without the need for additional enquiry (beginning and aim of the trip, choice of trajectory, distance travelled, speed, etc.);

- an option to check the data - for instance, capturing unreported activities; and

- an option of simple connection with other digital databases (public transport network, address points, etc.).

The extent to which the GPS is able to provide more accurate information about an individual's movement in space, and whether there is the option for the total replacement of the classic data collection method by such a technology, is examined in this article. As mentioned by Bricka et al. (2012), the role of GPS has been primarily designed for the purpose of evaluating the accuracy of trip reporting - identifying trips recorded in the GPS data streams that were not reported by the respondents in the diaries. Analyses of these non-reported trips have provided critical insights that have led to improvements in the survey materials and data collection methods, resulting in improved capture of trips via diaries. The following method of time-space recording not only uses the GPS device as a supplement for the trip corrections, but also as an integral part of research. The key role is played by the synchronization of diary data with the GPS record.

\subsection{The synchronization of time-space diary and GPS records}

The basic methodological procedure for synchronization of the GPS records with time-space diaries is presented. Synchronization of the two records at first glance appears to be a simple process - individual activities should be assigned to particular spatial data points, based on time consistency between the diary and route record from the GPS logger. But the GPS device records continuously the position and therefore contains an enormous amount of data, which must be adjusted. Respondents, too, do not always complete the diaries correctly. This may lead to an erroneous interpretation or an over-generalisation of the route record. The following steps must be carried out for the synchronization of time-space diaries and GPS records. Fig. 1 represents the workflow scheme.

Stages are reported in order here. The GPS Data cleaning stage: location-positioning errors are inevitable in the data obtained by the GPS device. The first step in data processing, then, is termed: cleaning. The tracklog contains redundant records, which need to be deleted.

The episode of GPS track, during which the individual stays at one place (station), can be due to an inaccurate satellite signal recorded as a movement. This can lead to the formation of a "bundle" of unrealistic movements. For instance, GPS units will show dislocation in space even when an individual is moving within the same building or shopping complex, resulting in activity-bundling within a confined space. Bricka et al. (2012) consider the threshold of acceptable dislocation to be a challenging issue in trip detection algorithms. Therefore the method presented here relies on manual identification of stations, using information from diaries (stations of home, work...) and map sources (e.g. the centre of building where the activity is carried out). By identifying an activity and its specific spatial anchoring, we are able to clean the GPS recorded track from unrealistic 


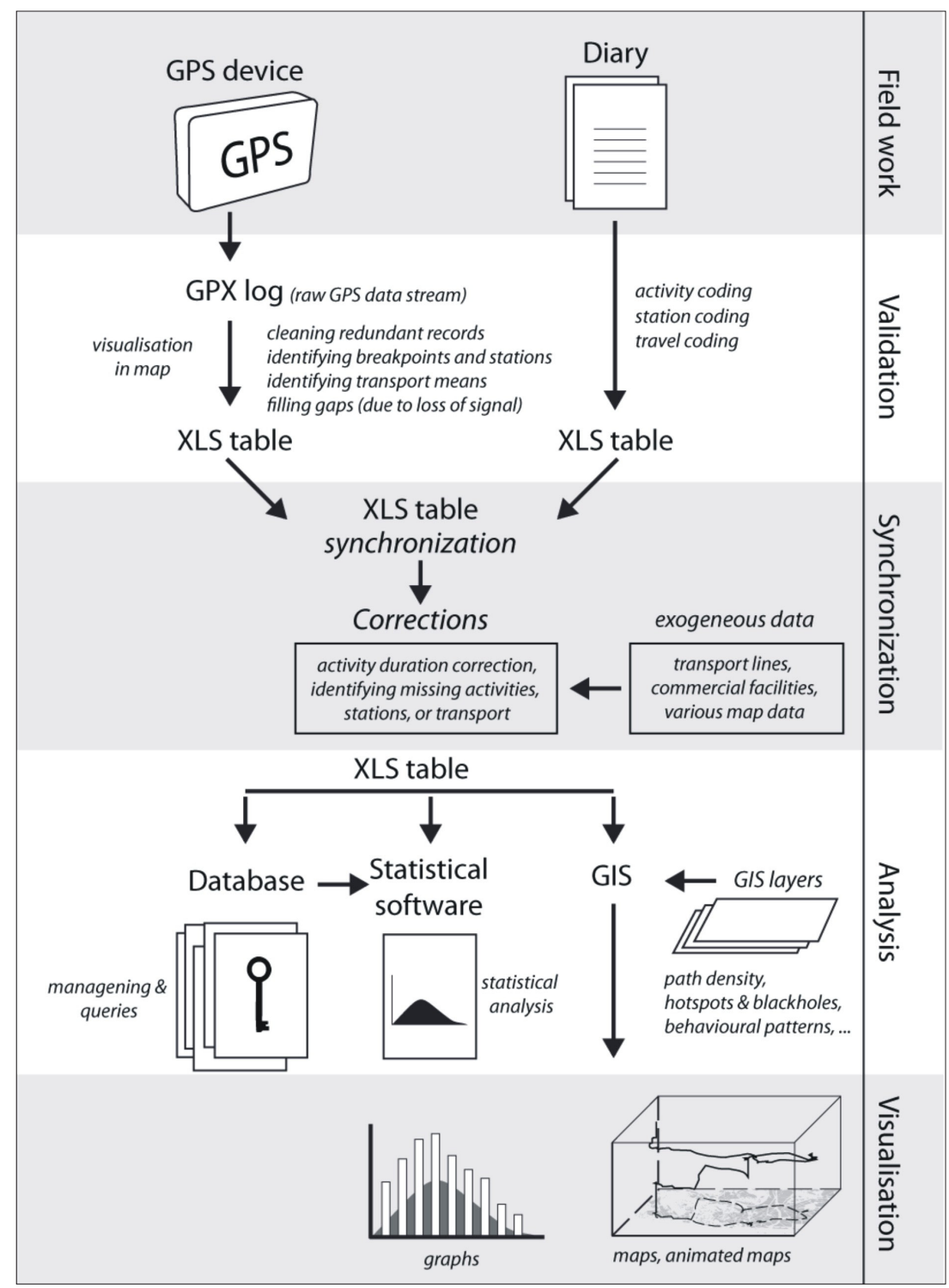

Fig. 1: Merging the time-space diary data and GPS tracklog: the workflow scheme. Source: authors

movements, and simplify the path to two points with the same spatial coordinates for input and output time of an individual at the station (Fig. 2).

To increase the accuracy of the record, it is appropriate to integrate and align spatial data with the road and settlement network. The record may slightly deflect from the road network if the GPS signal is shaded (e.g. in transport means). Especially in highly urbanized areas with a dense urban structure, the position accuracy of GPS decreases. The radio signals sent by the GPS satellites are too weak to penetrate through narrow urban canyons. This is known as the Urban Canyon Effect phenomenon. Mostly, we can correct the inaccuracies in GPS records by adjusting points for the transport network and settlement structure (Fig. 2). Using a web mapping service application (e.g. Google Maps), we are able to get an amount of additional information such as public transportation and various points of interest.

For the identification of breakpoints, a key step is the identification of breakpoints in the route record as, for instance, distinct spatial or temporal leaps or an abrupt change in speed or direction of movement (Mountain and Raper, 2001). Such breakpoints can be used for the delimitation of episodes in a respondent's trajectory (Fig. 2).
One episode should contain a relatively homogeneous timespatial record (for instance a trip by car).

The principal indicators of breakpoints are:

- any changes in frequency of the time route record. Sudden prolongation or shortening of interval follows after a relatively regular time route record;

- an abrupt change of speed or direction of movement. For instance, change of transport means (car - walking) or a 180-degree turn (trip of a parent from home to school and back);

- leaving the spatial frame (envelope) represented by the polygon delimiting a certain scope of a spatial record of the position when staying in a station. The merging of route points under certain spatial/temporal delimitations enables the simplification of the route record.

The indicator of the speed of movement is suitable not only for the separation of individual route segments (episodes), but it can be also used for determination of the way of transport in the case when the information on transport usage is missing in the diary. As is obvious from Tab. 1, each basic type of transport is characterised by certain mean speed. All points of the route segment which have a speed recorded in a certain interval identify the particular ways 
of transport. For example, certain route segments with a speed under $7 \mathrm{~km} \cdot \mathrm{h}^{-1}$ represent walking. For a method for dividing trajectories into activity (single-mode segments) and their classification according to the transportation mode used, see Biljecki et al. (2012). An aid for the identification of the particular type of transport can also be an observation of the used infrastructure (road, rail) and the beginning (end) of the route segment, in certain particular places (e.g. a stop in the public transport system). The combination of GPS and diary data does not require setting tolerances for breakpoints and the automatic determination of transport means, as mentioned in diary data. The speed data, however, make the delimitation of episodes (trips, rides) easier.
For the activity duration and coding, the following is noted: as respondents do not put down accomplished activities immediately after they end but some time afterwards, their actual duration is often biased. While respondents can precisely estimate duration of some types of (routine) activities (trip to work, trip to language school, etc.), in the case of less frequent activities the duration may be rounded (e.g. stroll in the park). If such activities do not take place in one station only (e.g. in the case of working from home) but are distributed among several stations, the duration of the activity linked to the given station (e.g. shopping in the market) or transport (change of direction and speed of movement in the place of the stop, etc.) can be established

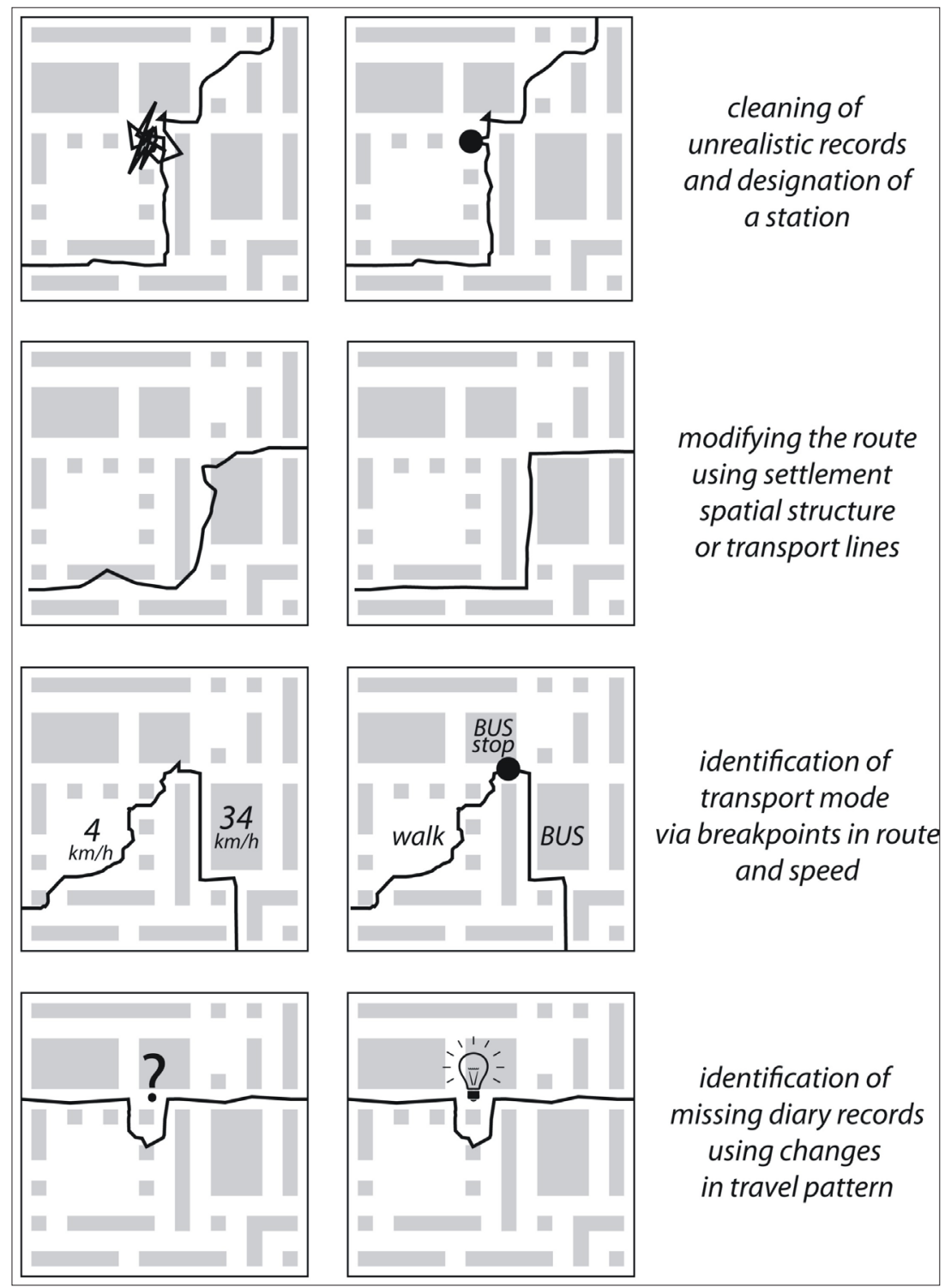

Fig. 2: Correction of route using multilevel data from tracklog, time-space diary and exogenous data (maps, transport lines, various points of interest e.g.). Source: authors

\begin{tabular}{|c|c|c|c|c|}
\hline Transport mode & Fixed route & Fixed stops & $\begin{array}{c}\text { Average speed } \\
{\left[\mathbf{k m}^{-1} \mathbf{l}\right]}\end{array}$ & $\begin{array}{c}\text { Max. speed } \\
{\left[\mathbf{k m}^{-\mathbf{1}}\right]}\end{array}$ \\
\hline Walk & No & No & 4 & 7 \\
Tram & Yes & Yes & 20 & 60 \\
Bus & Yes & Yes & 30 & 90 \\
Car & No & No & $40-50$ & 130 \\
\hline
\end{tabular}

Tab. 1: Characteristics of transport means regarding route record via GPS. Source:authors 
more precisely by means of input and output times. For example, if a respondent notes that $\mathrm{s} /$ he spent 15 minutes at a grocery store, but from the input and output times of the GPS tracklog, we find out that the shopping took only 9 minutes. Such traceability is crucial in estimating activity duration.

Simultaneously with specifying activity duration, we define activities by a coding scheme. Gathering and coding activity data requires an understanding of what activities should be captured and how they should be structured. There are many activity coding schemes (see for example, Harvey, 2003) suitable for different research perspectives (social, travel, economic, etc.).

As far as synchronization is concerned, the results of the adjustments mentioned above are merging the diary records (Tab. 2) with those of the GPS logger (Tab. 3), into a single table (Tab. 4), which contains the duration of individual activities along with their spatial location, as well as the spatial trajectories of the individual's movement. As each activity has not only duration but also spatial coordinates, it is recorded in the table in two lines (for the beginning and the end points). In the case of activities bound to one station, coordinates of its beginning and end will be the same and it will be represented in time-spatial visualisation (3D) by a vertical line segment.

After these steps, we are able to import the data into the GIS system, which provides comprehensive data on many aspects of the environment and transportation systems. These contextual data allow the activity-travel data to be related to the geographical environment of a region during the visualization (see Kwan, 2004). Fig. 3 shows the visualization of the time-space paths of two families from the survey.

\section{Assessment of accuracy and reliability of the combined record}

The reliability and precision of the route record were tested on a sample of 60 respondents, who obtained a small briefcase with the diary and a GPS device. We used the GPS logger Holux M-1000C, which has the size of a match-box, weighs only $60 \mathrm{~g}$ and is able to record the position with a precision of \pm 3 metres (66 channels, sensitivity - $162 \mathrm{dBm}$ ). Participants were instructed in how to carry the GPS logger (e.g. attached to purse, keys, or bag) and how to regularly update the diary during the 24-hour period (the battery of the device holds the charge for around 30 hours). Respondent selection was based on the following criteria: testing the survey method in varied conditions (town, rural area, shopping mall, transport means, etc.), with the aim to optimise the setting of record frequency and processing.

The following (recommendations) were identified:

- the wearable GPS device should be small in size and lightweight, so that it does not bother the respondent during the survey. The device may be easily clipped to keys, backpack or purse, so that the risks, such as not carrying the GPS device correctly or forgetting to carry it at all, are minimized;

- it is appropriate to optimize the trip detection algorithms by finding a balance between a too sensitive record (over-identifying trips) or not sensitive enough (underidentifying trips). The recording interval should be in accordance with the objectives and scale of research,

\begin{tabular}{|c|c|c|c|c|c|}
\hline Time & Activity & Where? & With who? & Travel & $\begin{array}{c}\text { Parallel } \\
\text { activity }\end{array}$ \\
\hline 0:00-6:30 & sleeping & at home & & & \\
$6: 30-6: 45$ & personal care & at home & & & \\
$6: 45-6: 50$ & meal preparing & at home & husband & & watching TV \\
$6: 50-7: 05$ & braekfast & at home & husband & & watching TV \\
$7: 05-7: 15$ & hosework & at home & & & \\
$7: 15-7: 30$ & dressing & at home & & & \\
$7: 30-8: 00$ & travel to work & & husband & car & \\
$\ldots$ & $\ldots$ & $\ldots$ & $\ldots$ & $\ldots$ \\
\hline
\end{tabular}

Tab. 2: The record from 24-hour activity diary. Source: authors

\begin{tabular}{|c|c|c|c|c|c|}
\hline ID-GPS & Local time & Latitude [ ${ }^{\circ}$ ] & Longitude [ ${ }^{\circ}$ ] & Altitude* & $\begin{array}{c}\text { Speed } \\
{\left[\mathbf{k m}^{\mathbf{- 1}}\right]^{*}}\end{array}$ \\
\hline 1 & $6: 24: 33$ & 48.27319 & 17.016890 & 179 & 0.2 \\
2 & $6: 24: 38$ & 48.27319 & 17.016890 & 179 & 0.1 \\
3 & $6: 25: 11$ & 48.27319 & 17.016890 & 179 & 0.3 \\
$\ldots$ & $\ldots$ & $\ldots$ & $\ldots$ & $\ldots$ & $\ldots$ \\
125 & $7: 23: 15$ & 48.27319 & 17.016890 & 179 & 0.1 \\
126 & $7: 24: 11$ & 48.27319 & 17.016890 & 179 & 1.1 \\
127 & $7: 24: 54$ & 48.27319 & 17.016966 & 162 & 12.1 \\
128 & $7: 24: 57$ & 48.27321 & 17.016756 & 162 & 20.0 \\
$\ldots$ & $\ldots$ & $\ldots$ & $\ldots$ & $\ldots$ & $\ldots$ \\
\hline
\end{tabular}

Tab. 3: The record from the GPS logger. Source: authors.

* Height above ellipsoid WGS84 


\begin{tabular}{|c|c|c|c|c|c|c|c|c|c|c|c|}
\hline 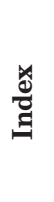 & 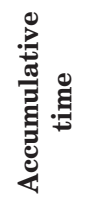 & 曾 & 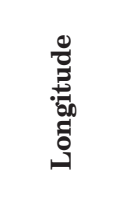 & $\begin{array}{l}\text { ठ্ँ } \\
\text { के } \\
\text { की }\end{array}$ & 突 & 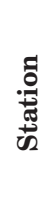 & 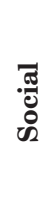 & D & 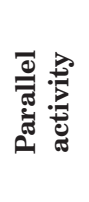 & 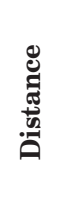 & 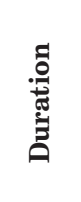 \\
\hline 0 & 0.0 & 48.27319 & 17.01689 & 0 & $\mathrm{~S} 1$ & S1 & & & & & 384.0 \\
\hline 1 & 384.0 & 48.27319 & 17.01689 & 0 & $\mathrm{~S} 1$ & S1 & & & & & 0.0 \\
\hline 2 & 384.0 & 48.27319 & 17.01689 & 0 & $\mathrm{~S} 2$ & S1 & & & & & 21.0 \\
\hline 3 & 405.0 & 48.27319 & 17.01689 & 0 & S2 & S1 & & & & & 0.0 \\
\hline 4 & 405.0 & 48.27319 & 17.01689 & 0 & S3 & S1 & $\mathrm{P} 1$ & & V8 & & 5.0 \\
\hline 5 & 410.0 & 48.27319 & 17.01689 & 0 & S3 & $\mathrm{S} 1$ & $\mathrm{P} 1$ & & V8 & & 0.0 \\
\hline 6 & 410.0 & 48.27319 & 17.01689 & 0 & S3 & $\mathrm{S} 1$ & $\mathrm{P} 1$ & & V8 & & 15.0 \\
\hline 7 & 425.0 & 48.27319 & 17.01689 & 0 & S3 & S1 & $\mathrm{P} 1$ & & V8 & & 0.0 \\
\hline 8 & 425.0 & 48.27319 & 17.01689 & 0 & $\mathrm{~S} 4$ & $\mathrm{~S} 1$ & & & & & 10.0 \\
\hline 9 & 435.0 & 48.27319 & 17.01689 & 0 & $\mathrm{~S} 4$ & $\mathrm{~S} 1$ & & & & & 0.0 \\
\hline 10 & 435.0 & 48.27319 & 17.01689 & 0 & $\mathrm{~S} 2$ & $\mathrm{~S} 1$ & & & & & 9.9 \\
\hline 11 & 444.9 & 48.27319 & 17.01689 & 0 & S2 & S1 & & & & & 0.0 \\
\hline 12 & 444.9 & 48.27319 & 17.01696 & 12.1 & $\mathrm{D}$ & & & D8 & & 8.7 & 0.1 \\
\hline 13 & 445.0 & 48.27321 & 17.01675 & 20.0 & $\mathrm{D}$ & & & D8 & & 9.5 & 0.1 \\
\hline 14 & 445.1 & 48.27322 & 17.01660 & 20.4 & $\mathrm{D}$ & & & D8 & & 9.3 & 0.1 \\
\hline
\end{tabular}

Tab. 4: Route record with assigned diary and GPS data. Source:authors

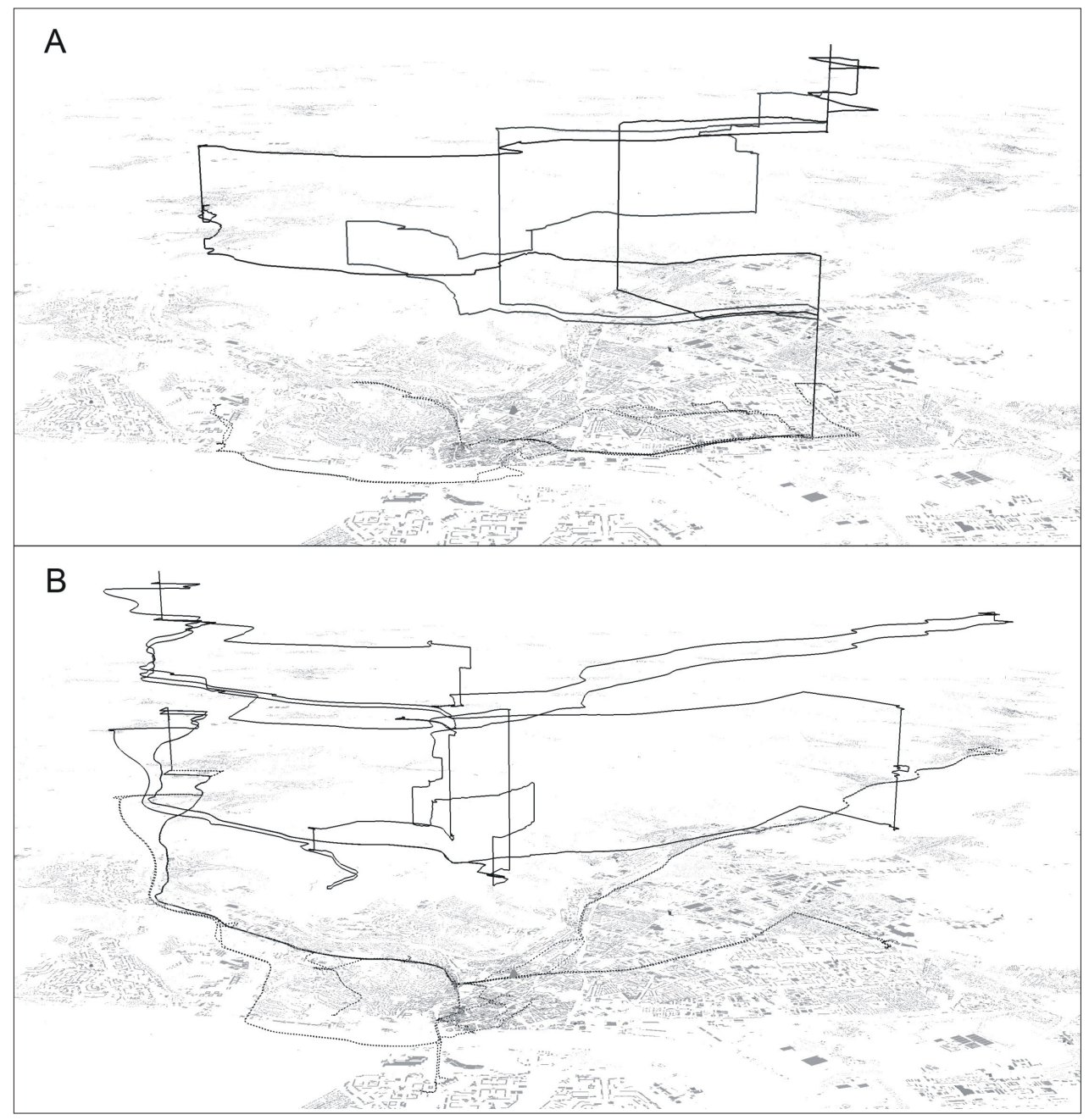

Fig. 3: The visualization of time-space paths of two families (eight individuals) in Bratislava (Slovakia). Family "A" lives in the city centre, family " $B$ " in the suburban zone. The different spatio-temporal pattern is obvious.

Source: authors 
we suggest an interval no longer than 10 seconds, respectively 20 meters;

- it is also necessary to consider the effect of a "cold start", which can take several minutes to download data from the satellites that describe the position and timing of all of the satellites in the system. We can avoid this effect by updating the navigation message ${ }^{1}$ just before the beginning of a survey.

The two most probable reasons for trips not being identified in the GPS unit-based streams, but being reported in the survey data, were (i) forgetfulness on the part of the respondent to take the device during one or more trips, and (ii) GPS device problems (Stopher and Shen, 2011). There is not much the researcher can do to counteract the unreliability of human memory, but we should consider the mis-reporting due to loss of GPS signal (see section 2.3).

Many prior GPS studies have focused on under-reporting of trips in household travel studies (see Bricka et al., 2012). The potential of combined diary-GPS survey is to identify under-reporting of trips and activities in self-reported surveys. The under-reporting can be caused by the memory decay of respondent, failure to follow survey instructions, respondents considering the activities or trips unimportant, or unwillingness to report full details (Wolf et al., 2003). Oft-forgotten or omitted activities in our pilot survey were activities (or trips) that occur as part of a trip chain (e.g. waiting at a bus stop, making coffee at work) or activities of short duration (under 10 minutes) that were missed due to forgetfulness of the respondent, or the lack of importance given by the respondent to the activity (mainly activities of self-care and communication).

Activities are the crucial element supporting the logical structure of a diary, and are the reason why the first column of the diary represents the activity record and not that of time (Fig. 4). It is more natural and more intuitive to quote: "What I am doing", and specify the time limit of the activity later. Open time intervals were used in the diary. Fixed intervals (for example 5 minutes) provide a clearer time structure (and simplify orientation in the diary), but regarding the option to synchronize diary and GPS records their use was not necessary, because in many cases it was possible to specify time limits of activities to the level of seconds.

There is the option to enclose a table of categories with pre-defined activity types for the time-space diary (Fig. 4). A respondent then chooses some of the offered activities (a comparatively large choice) and puts their codes into the diary. On the one hand, this makes the processing of data easier, but it also implies the risk of discouraging the respondents from participation because it is rather demanding. As reported by Kenyon (2006), the use of activity codes contributes to perceptions of time-space diary data as 'safe', in terms of privacy protection. On the other hand, freedom in activity recording, here preferred, brings the risk that the diary will not be kept with sufficient detail. The natural effort of a researcher is to obtain the most detailed data possible, but it has to be borne in mind that a detailed record is not only more demanding on data collection but also on processing. Any attempt to reach a high spatio-temporal resolution may produce a counterproductive result. As Kenyon (2006) reports, there is a danger that, in the effort to capture everything, at the end very little is detected. It is then appropriate to have the time-space diary adapted to the specific features of the given research parameters (transport, social, economic, etc.). Enclosure of examples of different activities to the diary proved to be helpful (Fig. 4). From this process, a more accurate record was obtained because the respondents were aware of the degree of specificity of the activity records that was expected. The records reveal that respondents often found inspiration in an enclosed activity list, and quoted such activities which they would have previously considered unworthy of recording (personal hygiene, surfing on the web, etc.).

\section{Alternative ways of time-space tracking}

The method of dual GPS-diary records presented here is obviously not the only way to track space-time movement. The potential use of mobile communication devices in travel and behaviour research has been discussed within the field for many years. Among many approaches, two general techniques are emphasised here with a brief discussion of their pros and cons.

The first method is based on tracking mobile telephones using the precision of network cells of mobile operators. There are different locational methods used by operators to determine the position of a mobile phone within their network. These locational methods have been an inherent component of the mobile phone service since the 1980s in order to be able to find where a mobile phone is and where a call has to be routed to, as well as to facilitate a seamless transfer of a telephone call between base stations, whilst the mobile phone is moving through space (Mateos, 2005). In general, mobile positioning data are similar to movement data gathered using GPS. The mobile positioning data have location coordinates and a time coordinate (Ahas et al., 2010). The major difference is in the spatial accuracy, which depends on the architecture of the GSM network and the density of the transmitter stations (Novák, 2010). In general the accuracy varies from $100 \mathrm{~m}$ (city centres) to $5,000 \mathrm{~m}$ (rural areas)

The most important research activity in this field in Europe is perhaps that carried out by the University of Tartu. The experiments in Estonia have used active and passive mobile positioning data. Active mobile positioning (active tracking) data are collected after a special query/request to determine the location of a mobile telephone (Ahas and Mark, 2005; Ahas et al., 2010). Passive mobile positioning data (passive tracking) is collected from secondary sources such as the memory or log files of mobile operators (Ahas et al., 2007b, 2008). A detailed insight into the use of mobile telephones as part of the study of individual behaviours was presented by Asakura and Hato (2004), though they used the mobile phones "only" as a tool suitable for tracking the movement of individuals without taking into account the owners' (tracked objects) characteristics. On the contrary, Ahas and Mark (2005) developed a method describing spatial behavioural patterns of individuals based on a combination of position coordinates of their mobile phones and personal characteristics. They denoted this approach as the social positioning method. Using mobile phones as a data collection technique became a frequent topic in transport and

\footnotetext{
1 The navigation message is a continuous $50 \mathrm{bits} / \mathrm{second}$ data stream modulated onto the carrier signal of every satellite. It includes information on precise satellite position (ephemeris), satellite clock correction and other parameters. It takes 12.5 minutes to transmit all of the information.
} 


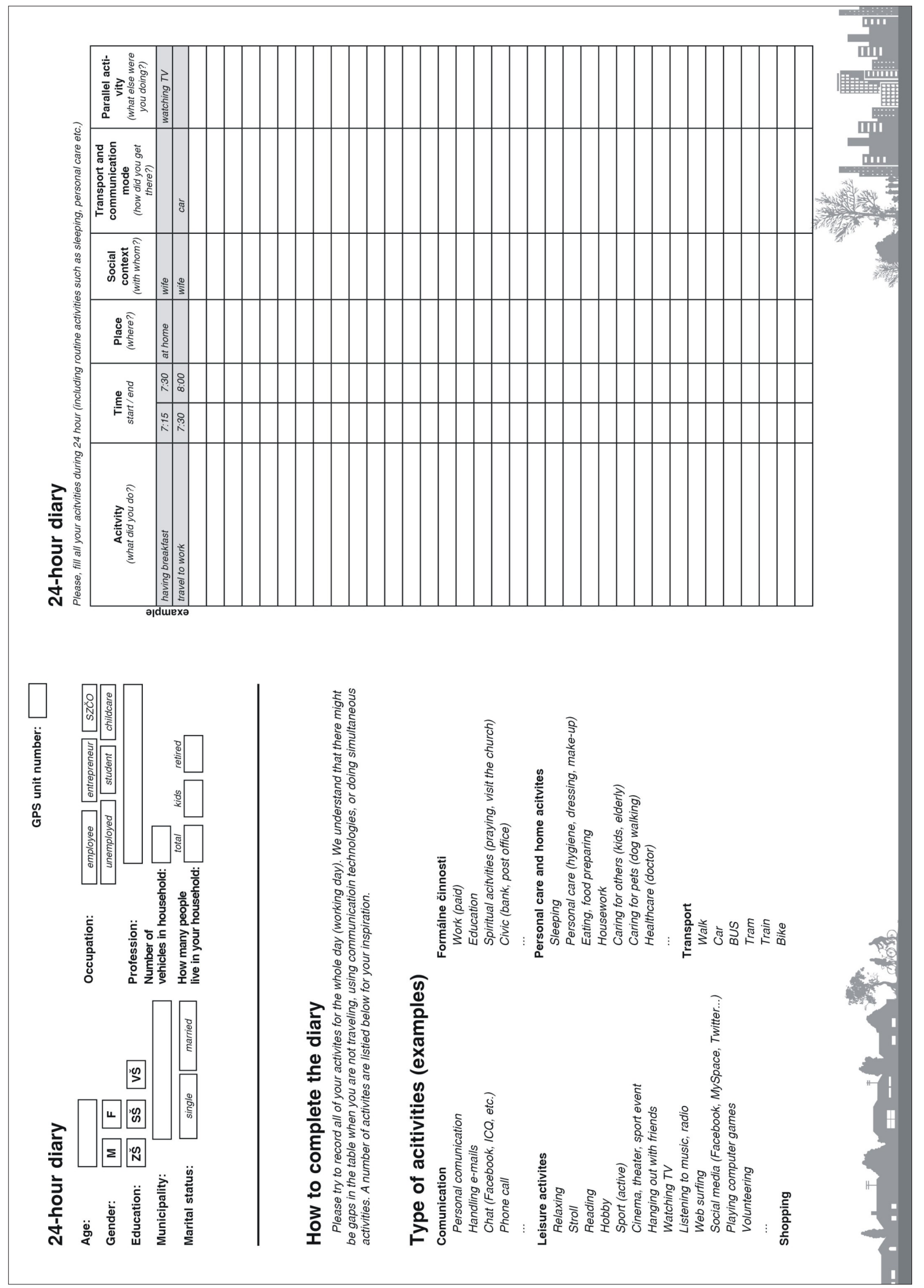

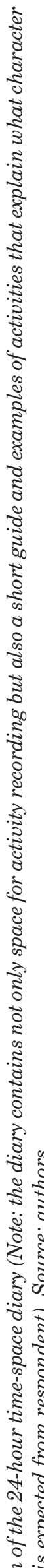

告.

से

षi

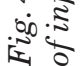


behavioural research (Ratti et al., 2005; Raubal et al., 2007; Yuan et al., 2012.). Novák and Temelová (2012) have examined the possibilities of mobile telephone location data combined with deep interpretative interviews.

According to Ahas et al. (2007a), localisation via mobile telephones while tracking an individual's movements is more suitable than GPS instruments. Mobile phones are widely accessible and technologies facilitating their location rapidly advance. It is possible to track a number of people simultaneously in real time and to obtain digital location data (Ahas et al., 2010). On the contrary, Novák and Temelová (2012) point out a possible inadequacy in usage of the mobile telephone location data (passive tracking) for the analysis of an individual's behaviour in terms of time geography, because the amount depends on the intensity of mobile telephone use. Naturally, there is also the question of potential privacy abuses of this technology (see Novák and Temelová, 2012). Particular attention should be paid to the handling of non-anonymous and disaggregated data. Some limited spatial accuracy of this method is suitable for regional-scale analyses of migration, commuting, traffic monitoring, tourism, etc.

The second approach is based on the new generation of telephones with the Assisted GPS function (A-GPS). It uses a combination of a GPS and a land-based antenna network to assist in obtaining a location. This technology was designed to supply a solution for locating mobile telephones in a cellular network at a resolution greater than the resolution possible using cellular triangulation (Shoval and Isaacson, 2006). The utilization of smart-phones with A-GPS creates new opportunities for time-space research, as it combines the high spatial accuracy of GPS and the accessibility of mobile phones (for a review, see Wolf et al., 2014). Undoubtedly, this method opens up new options for large-scale research, in the broadest sense of the word. But, at this time the massive utilization of A-GPS in time-space research is limited by the distribution of smartphones among the population, and by the development of an application to be used for data collection in which respondents' activities will be detected (realtime questions). Although the distribution of smartphones among the population is rapidly growing (with technology penetration), there are still mobile device users (e.g. elderly respondents) who do not use smartphones, potentially due to difficulty or plain dislike of the product. According to Wolf et al. (2014), there are still a few technological and methodological challenges to overcome before smartphone solutions can become dominant in activity and travel surveys. As these authors assert, such challenges include:

a. market fragmentation - it is difficult and costly to develop apps for multiple platforms and operating system versions to support the majority of participants with smartphones;

b. power management - continuously logging GPS data will rapidly deplete a smartphone battery; and

c. data plans and associated costs - participants may have limitations on their data plans.

Both approaches of using devices owned by participants (mobile telephones) can address common implementation challenges in GPS-based surveys by: (a) eliminating the need to ship out and retrieve GPS loggers; (b) shortening the time between travel date collection and data review; and (c) reducing costs (Bricka and Murakami, 2012). Localization via mobile telephones undoubtedly brings new opportunities for time-space research. While the GPS instruments are highly accurate and provide a strictly individualised record, tracking via mobile phones offers the possibility of (regular) collection of a great volume of spatial data. The approach of mobile-phone-based tracking has proven its applicability in large-scale research (e.g. Ahas et al., 2007b, 2010), but the potential arising from the use of A-GPS technology is waiting for breakthroughs in the methodology. Tab. 5 summarizes and compares selected properties of mobile-phone-based localization and localization by GPS (conventional tracking by GPS-logger). The purpose of this comparison is to show the range of current data requirements in time-space surveys to be considered when evaluating various data sources to replace conventional surveys.

\section{Conclusions}

GPS technology seems to be a suitable tool for the collection of individually-coded and spatially-located data. It not only represents a more sophisticated tool for the collection of spatial data but it is also a phenomenon, which helps to achieve a more correct analysis of peoples' spatial behaviour. The data obtained by the combined GPS device and conventional data collection methods via timespace diaries, supplement and specify each other. Taking into account certain constraints of the GPS technology, researchers are able to acquire very accurate and detailed individual spatial trajectories.

\begin{tabular}{|l|l|l|l|}
\hline & \multicolumn{1}{|c|}{ GPS localization } & $\begin{array}{l}\text { Mobile-phone-based localization } \\
\text { via transmitter stations }\end{array}$ & $\begin{array}{l}\text { Mobile-phone-based localization } \\
\text { via A-GPS }\end{array}$ \\
\hline \multirow{3}{*}{$\begin{array}{l}\text { Principle } \\
\text { of operation }\end{array}$} & $\begin{array}{l}\text { Positioning data is collected from } \\
\text { the memory of GPS device. Passive } \\
\text { record, with the possibility of setting } \\
\text { variable parameters (time frequency, } \\
\text { distance frequency, speed limitation. }\end{array}$ & $\begin{array}{l}\text { The principle of operation is based } \\
\text { on localization of mobile phone } \\
\text { via transmitter stations. We can } \\
\text { distinguish two approaches: Active } \\
\text { mobile positioning data is collected } \\
\text { after a query/request to determine the } \\
\text { location of a mobile phone. Passive } \\
\text { mobile positioning data is collected } \\
\text { from secondary sources such as the } \\
\text { memory or log files of mobile operators }\end{array}$ & $\begin{array}{l}\text { The principle of operation is based } \\
\text { on the mobile phones with the } \\
\text { Assisted GPS function (A-GPS). It } \\
\text { uses a combination of a GPS and } \\
\text { a land-based antenna network to } \\
\text { assist in obtaining a location. Active } \\
\text { use - respondents use the phone } \\
\text { application to respond to survey } \\
\text { questions during the day (activities, } \\
\text { type of stations, transport means). } \\
\text { Passive use - all recordings take place } \\
\text { automatically in the background, } \\
\text { with the application transmitting the } \\
\text { captured data for processing }\end{array}$ \\
\hline
\end{tabular}

Tab. 5: Comparison of basic characteristics of location by GPS and by mobile phone

Source: authors, characteristics of active mobile positioning data have been processed according to work Novák (2010) and Novák, Temelová (2012). 


\begin{tabular}{|c|c|c|c|}
\hline & GPS localization & $\begin{array}{l}\text { Mobile-phone-based localization } \\
\text { via transmitter stations }\end{array}$ & $\begin{array}{c}\text { Mobile-phone-based localization } \\
\text { via A-GPS }\end{array}$ \\
\hline $\begin{array}{l}\text { Spatial } \\
\text { accuracy }\end{array}$ & $\begin{array}{l}3-20 \text { meters, accuracy is reduces in } \\
\text { areas with limited open-sky view (e.g. } \\
\text { in dense forest) }\end{array}$ & $\begin{array}{l}\text { Depends on the architecture of GSM } \\
\text { network and density of transmitter } \\
\text { stations. Accuracy varies from } 100 \text { to } \\
5000 \text { meters }\end{array}$ & $\begin{array}{l}\text { Depends on the device and network } \\
\text { specifications, in case of combination } \\
\text { of GPS, GSM and Wi-fi it can be } \\
\text { up to a few meters. Localization is } \\
\text { supported also in areas with limited } \\
\text { open-sky view and confined spaces. }\end{array}$ \\
\hline $\begin{array}{l}\text { Impediment } \\
\text { to accuracy }\end{array}$ & $\begin{array}{l}\text { Urban canyon effect, start up time to } \\
\text { first fix, unreal records while staying } \\
\text { in buildings. }\end{array}$ & $\begin{array}{l}\text { Variable connection of non-movement } \\
\text { mobile phone to different base } \\
\text { transceiver station („hand over noise“) }\end{array}$ & $\begin{array}{l}\text { Depends on the device and network } \\
\text { specifications }\end{array}$ \\
\hline $\begin{array}{l}\text { Frequency } \\
\text { of record }\end{array}$ & Seconds & Minutes & Seconds \\
\hline Survey size & Sample group & Sample group or all mobile phone users & Sample group \\
\hline Requirements & $\begin{array}{l}\text { Open-sky environment (view of three } \\
\text { or more GPS satellites) }\end{array}$ & GSM signal coverage & $\begin{array}{l}\text { Specialized application transmitting } \\
\text { the captured data, connection to an } \\
\text { internet servis provider. Data access } \\
\text { (which can cost money) depends on the } \\
\text { data plan with the mobile operator. }\end{array}$ \\
\hline $\begin{array}{l}\text { Battery } \\
\text { preservation }\end{array}$ & $\begin{array}{l}\text { Depends on battery life, usually 18-30 } \\
\text { hours. }\end{array}$ & $\begin{array}{l}\text { The need to have charged mobile } \\
\text { phone allows practically unlimited } \\
\text { endurance. }\end{array}$ & $\begin{array}{l}\text { The need to have charged mobile } \\
\text { phone allows practically unlimited } \\
\text { endurance; however, using GPS } \\
\text { reduces battery life. }\end{array}$ \\
\hline $\begin{array}{l}\text { Cooperation } \\
\text { needed }\end{array}$ & $\begin{array}{l}\text { Demands a higher level of cooperation } \\
\text { from the subject, especially during } \\
\text { a multi-day record (forgetfulness to } \\
\text { take the device, switch off the device, } \\
\text { battery discharge) }\end{array}$ & $\begin{array}{l}\text { The need to have a mobile phone } \\
\text { during whole day contributes to the } \\
\text { reliability of data collection }\end{array}$ & $\begin{array}{l}\text { The need to have a mobile phone } \\
\text { during whole day contributes to the } \\
\text { reliability of data collection. }\end{array}$ \\
\hline $\begin{array}{l}\text { Type of data } \\
\text { obtained }\end{array}$ & $\begin{array}{l}\text { Geographic coordinates, speed, } \\
\text { distance, altitude, time }\end{array}$ & Geographic coordinates, time & $\begin{array}{l}\text { Geographic coordinates, speed, } \\
\text { distance, altitude and time. Activities, } \\
\text { transport means and other survey } \\
\text { questions can be asked via special } \\
\text { application. }\end{array}$ \\
\hline Privacy & $\begin{array}{l}\text { User controlled. Personal contact } \\
\text { with the respondent allows obtaining } \\
\text { informed consent. }\end{array}$ & $\begin{array}{l}\text { Passive localization: the need to } \\
\text { apply an anonymisation algorithm } \\
\text { to the raw data before processing. } \\
\text { Active localization: personal contact } \\
\text { with the respondent allows obtaining } \\
\text { informed consent. }\end{array}$ & $\begin{array}{l}\text { Location using the system is user } \\
\text { controlled. Personal contact with the } \\
\text { respondent allows obtaining informed } \\
\text { consent. }\end{array}$ \\
\hline Processing & $\begin{array}{l}\text { The need of cleaning the record of } \\
\text { unrealistic trajectories (mostly during } \\
\text { the stay at confined area) }\end{array}$ & $\begin{array}{l}\text { The need for "cleaning" algorithms to } \\
\text { eliminate unrealistic records, which } \\
\text { are caused by variable connection } \\
\text { of non-movement mobile-phone to } \\
\text { different base transceiver station }\end{array}$ & $\begin{array}{l}\text { Depends on survey application } \\
\text { architecture }\end{array}$ \\
\hline $\begin{array}{l}\text { Overall } \\
\text { characteristic }\end{array}$ & $\begin{array}{l}\text { Position and time accuracy allow to } \\
\text { record not only time-space path, but } \\
\text { also identify vehicle used, or time and } \\
\text { space collocation (e.g. members of } \\
\text { household). Higher demands on the } \\
\text { cooperation are in the necessity to } \\
\text { recharge the batteries if the survey } \\
\text { exceeds } 24 \text { hours. Carrying GPS device } \\
\text { can sometimes be annoying even } \\
\text { when the size of the device is compact } \\
\text { and wearable. The costs of data } \\
\text { collection (hardware and labour costs } \\
\text { of data collectors) is acceptable and is } \\
\text { compensated by the quality of data. }\end{array}$ & $\begin{array}{l}\text { High penetration rate of mobile } \\
\text { phones in population enables } \\
\text { large-scale tracking surveys, } \\
\text { possibility of continuous recording } \\
\text { over longer periods of time, less } \\
\text { expensive in terms of hardware and } \\
\text { communication costs. Unresolved } \\
\text { legal and ethical issues. Dependence } \\
\text { on cooperation with mobile operators. }\end{array}$ & $\begin{array}{l}\text { High penetration rate of mobile } \\
\text { phones in population enables large- } \\
\text { scale tracking surveys. Automated } \\
\text { collection of real-time data is possible. } \\
\text { However, it is neccessery to develop } \\
\text { an application for data collection } \\
\text { in which respondents'activities } \\
\text { will be detected. Few technological } \\
\text { and methodological challenges } \\
\text { to overcome. Some population } \\
\text { groups (elderly people) may not be } \\
\text { represented in the data sample. }\end{array}$ \\
\hline
\end{tabular}


Synchronization and linking with the diaries yields a powerful tool for spatio-temporal research, facilitating an insight into the complexity of everyday spatial and social interactions of individuals. The principal positive features of the methods presented here include their high levels of spatio-temporal accuracy, the option to reveal unrecorded activities and the record of speed, or the option to interlink the route record with different digital databases (public transport network, shops, address points, etc.).

Future time-space surveys will undoubtedly rest on automated data collection, using mobile telephones with inbuilt GPS modules and communications with the user via specialised applications. Providing respondents with the option to use their own device for data collection can reduce costs, as well as increase the likelihood that the respondent will remember to carry the device. Research in the field of location-based technologies using the advanced architecture of various software applications (Raper et al., 2007; Lathia et al., 2013; Wolf et al., 2014), which are able to capture individual behaviours in real time, also seem to be very promising. Some population sub-groups, such as the elderly or low income residents, has been slower to use consumer products such as smartphones and, therefore, may not be represented in the data samples (how many people use smartphones?, and is the user group demographically biased?). Therefore, to provide a representative sample, it is necessary to design a universal survey system that requires a minimum operation of data collection devices. From this point of view, the method of a combined GPS-diary records system, as presented here, can be considered a formally simple, practically very reliable, and an affordable way of recording individual spatio-temporal data.

Time geography does not answer a lot of why and how questions, but that is due to its general nature. What it does is to form a basis for asking these types of indispensable questions (Lenntorp, 2003). In a similar view, we should consider methods of space-time research as general methodological bases rather than as precisely calibrated tools. The method presented in this article allows a deeper understanding of the organization of everyday activities and the spatial trajectories of individuals, and there are many areas in social science research where this method can be fruitfully applied. In particular applications, it is necessary to adapt the parameters and scale of the method for local circumstances.

\section{Acknowledgement}

This paper has been produced under the scientific project No. 1/0082/15 funded by the VEGA Grant Agency (Scientific Grant Agency of the Ministry of Education and the Slovak Academy of Sciences).

\section{References:}

AHAS, R., AASA, A., SILM, S., AUNAP, R., KALLE, H., MARK, Ü. (2007a): Mobile positioning in spacetime behaviour studies: social positioning method experiments in Estonia. Cartography and Geographic Information Science, 34(4): 259-273.

AHAS, R., AASA, A., MARK, Ü., PAE, T., KULL, A. (2007b): Seasonal tourism spaces in Estonia: case study with mobile positioning data. Tourism Management, 28(3): 898-910.
AHAS, R., AASA, A., ROOSE, A., MARK, Ü., SILM, S. (2008): Evaluating passive mobile positioning data for tourism surveys: an Estonian case study. Tourism Management, 29(3): 469-486.

AHAS, R., AASA, A., SILM, S., TIRU, M. (2010): Daily rhythms of suburban commuters movements in the Tallinn metropolitan area: Case study with mobile positioning data. Transportation Research, Part C, 18(1): 45-54.

AHAS, R., MARK, Ü. (2005): Location based services: new challenges for planning and public administration? Futures, 37(6): 547-561.

ASAKURA, Y., HATO, E. (2004): Tracking survey for individual travel behaviour using mobile communication instruments. Transportation Research, Part C, 12(3-4): 273-291.

ASAKURA, Y., HATO, E. (2009): Tracking Individual travel behaviour using mobile phones: recent technological development. In: Kitamura, R., Yoshii, T., Yamamoto, T. [eds.]: The Expanding Sphere of Travel Behaviour Research (pp. 207-236). Emerald Group Publishing Limited.

AULD, J.A., WILLIAMS, C., MOHAMMADIAN, A., NELSON, P. (2009): An Automated GPS-Based Prompted Recall Survey with Learning Algorithms. Transportation Letters: The International Journal of Transportation Research, 1(1): 59-79.

BILJECKI, F., LEDOUX, H., VAN OOSTEROM, P. (2012): Transportation mode-based segmentation and classification of movement trajectories. International Journal of Geographical Information Science, 27(2): 385-407.

BOSE, J., SHARP, J. (2005): Measurement of Travel Behavior in A Trip-Based Survey versus a Time-Use Survey: A Comparative Analysis of Travel Estimates Using the 2001 National Household Travel Survey and the 2003 American Time Use Survey, Paper presented at the American Time Use Survey: Early Results Conference, Washington D.C. 9.12.2005. [online]. [cit. 14.04.2014] Available at: http://www.atususers.umd.edu/papers/ atusconference/authors/BoseSharpSlides.pdf

BRICKA, S., MURAKAMI, E. (2012): Advances in travel survey technology. Proceedings of the $13^{\text {th }}$ International Conference on Travel Behaviour Research. Toronto, ISCTSC.

BRICKA, S., SEN, S. PALETI, R., BHAT, C. R. (2012): An Analysis of the Factors Influencing Differences in Survey-Reported and GPS-Recorded Trips. Transportation Research, Part C: Emerging Technologies, 21(1): 67-88.

BULIUNG, R., KANAROGLOU, P. (2006): A GIS toolkit for exploring geographies of household activity/travel behavior. Journal of Transport Geography, 14(1): 35-51.

CARLSTEIN, T., PARKER, D., THRIFT, N. J. (1978): Timing space and spacing time: Human Activity and Time Geography. Edward Arnold, London.

CHEN, C.-W., CHU, T.-H., LIN, M.-L., CHANG, C.-H. (2011): Using mobile geographic information system (GIS) techniques to develop a location-based tour guiding system based on user evaluations. International Journal of the Physical Sciences, 7(1): 121-131. 
DRAIJER, G., KALFS, N., PERDOK, J. (2000): Global Positioning System as data collection method for travel research. Transportation Research Record: Journal of the Transpotation Research Board, 1719(1): 147-153.

DRGOŇA, V., KRAMÁREKOVÁ, H., DUBCOVÁ, A. (1994): Mobilita chodcov v centrálnej časti mesta Nitra: pohlad geografov. Geografické štúdie, 3: 97-137.

GIAIMO, G. T., ANDERSON, R., WARGELIN, L. (2009): Large-scale deployment of a GPS-based household travel survey in Cincinnati. Paper presented at the $12^{\text {th }}$ TRB National Transportation Planning Applications Conference, Houston, Texas. [online]. [cit. 15.04.2014] Available at: http://www.powershow.com/view/186dfYTMzZ/ODOT_Greg_Giaimo_and_Rebekah_Anderson_ powerpoint_ppt_presentation

GOLLEDGE，G. R., KWAN, M.-P., GARLING, T. (1994): Computational process model of household travel decisions using a geographical information system. Papers in Regional Science, 73(2): 99-117.

HÄGERSTRAND, T. (1970): What about people in regional science? Paper presented at The Ninth European Congress of the Regional Science Association, [online]. [cit. 15.04.2014] Available at: http://courses.washington. edu/cee500/What $\% 20$ about $\% 20$ people $\% 20$ in $\% 20$ regional\%20science.pdf

HALLIN, P. O. (1991): New Paths for Time-Geography? Geografiska Annaler B: Human Geography, 73(3): 199-207.

HARVEY, A. S. (2003): Time-space diaries: Merging traditions. In: Stopher, P., Jones, P. [eds.]: Transport survey quality and innovation (pp. 152-180). Oxford, Elsevier.

IRA, V. (1986): Časovo-priestorový prístup v sociálnej geografii na príklade obce Lom nad Rimavicou. Sborník referátů ze sjezdu SGS v roce 1986, Banská Bystrica, SGS.

IRA, V. (2000): Vnútromestský pohyb človeka v čase a priestore (na príklade Bratislavy). In: Matlovič, R. [ed.]: Urbánny vývoj na rozhraní milénií. Urbánne a krajinné štúdie 3 (pp. 167-173). Prešov, FF PU.

IRA, V. (2001): Geografia času: prístup, základné koncepty a aplikácie. Geografický časopis, 53: 231-246.

JARVIS, H. (2005): Moving to London time, household coordination and the infrastructure of everyday life. Time \& Society, 14(133): 134-154.

JONG, R. D., MENSONIDES, W. (2003): Wearable GPS device as a data collection method for travel research, Working Paper ITS-WP-03-02, Institute of Transport Studies, University of Sydney. [online]. [cit. 15.04.2014] Available at: http://ws.econ.usyd.edu.au/itls/wp-archive/ itls-wp-03-02.pdf; ISSN 1440-3501

KENYON, S. (2006): The 'accessibility diary': discussing a new methodological approach to understand the impact of internet use upon personal travel and activity participation. Journal of Transport Geography, 14(2): 123-134.

KLAPKA, P., ROUBALÍKOVÁ, H. (2010): Places and students in urban environment: a time-geographical perspective. Geografický časopis, 62: 33-47.

KRYGSMAN, S., NEL, J.H. (2009): The use of global positioning devices in travel surveys - a developing country application, South Africa, Pretoria 6-9.7.2009. [online]. [cit. 15.04.2014] Available at: http://repository.
up.ac.za/bitstream/handle/2263/11954/Krygsman_ Use $\% 282009 \% 29$.pdf? sequence $=1$

KWAN, M.-P. (1998): Space-time and integral measures of individual accessibility: a comparative analysis using a point-based framework. Geographical Analysis, 30(3): 191-217.

KWAN, M.-P. (2000): Interactive geovisualization of activitytravel patterns using threedimensional geographical information systems: a methodological exploration with a large data set. Transportation Research C, 8: 185-203.

KWAN, M.-P. (2004): GIS Methods in Time-Geographic Research: Geocomputation and Geovisualization of Human Activity Patterns. Geografiska Annaler B: Human Geography, 86(4): 267-280.

KWAN, M.-P., HONG. X.-D. (1998): Network-based constraints-oriented choice set formation using GIS. Geographical Systems, 5: 139-162.

KWAN, M.-P, LEE, J. (2003): Geovisualization of human activity patterns using 3D GIS: a time-geographic approach. In: Goodchild, M. F., Janelle, D. G. [eds.]: Spatially integrated social science: examples in best practice (pp. 48-66). Oxford, Oxford University Press.

LATHIA, N., PEJOVIC, V., RACHURI, K., MASCOLO, C., MUSOLESI,M., RENTFROW, P. (2013): Smartphones for Large-Scale Behaviour Change Intervention. IEEE Pervasive Computing, 12(3).

LENNTORP, B. (1976): Paths in time-space environments: a time-geographic study of movement possibilities of individuals. Lund Studies in Geography No. 44. The Royal University of Lund, Sweden.

LENNTORP, B. (1999): Time-geography - at the end of its beginning. GeoJournal, 48(3): 155-158.

LENNTORP, B. (2003): The drama of real-life in a timegeographic disguise. Paper presented at the Sixth Theo Quant Meeting, Besancon, France [online]. [cit. 15.04.2014] Available at: http://thema.univfcomte.fr/ theoq/pdf/2003/03Lenntorp.pdf

MADAJOVÁ, M., ŠVEDA, M. (2013): Geografia času pod vplyvom informačno-komunikačných technológií, Geografie 2: 179-203.

MATEOS, P. (2005): Mapping the space of flows: evaluating mobile phone location as a method to track the mobile society. CUPUM2005 Conference, London.

MILLER, H. J. (1991): Modeling accessibility using spacetime prism concepts within geographical information systems. International Journal of Geographical Information Systems, 5(3): 287-301.

MILLER, H. J. (2005): Necessary space - time conditions for human interaction. Environment and Planning B: Planning and Design, 32(3): 381-401.

MILLER, H. J., BRIDWELL, S. (2009): A field-based theory for time geography. Annals of the Association of American Geographers, 99(1): 149-175.

MILLER, H. J., WU, Y.-H. (2000): GIS software for measuring space-time accessibility in transportation planning and analysis. GeoInformatica, 4(2): 141-159.

MOUNTAIN, D., RAPER, J. (2001): Modelling human spatio-temporal behaviour: a challenge for locationbased services. Paper presented at the $6^{\text {th }}$ International Conference on GeoComputation. University of 
Queensland, Brisbane. 24.-26.09.2001. [online]. [cit. 15.04.2014] Available at: http://www.geog.leeds.ac.uk/ groups/geocomp/2001/papers/mountain.pdf

MULÍČEK, O., OSMAN, R., SEIDENGLANZ, D. (2010): Časoprostorové rytmy města - industriální a postindustriální Brno. Československé město včera a dnes: každodennost, reprezentace, výzkum (pp. 195-220). Brno, Masarykova univerzita.

MURAKAMI, E., WAGNER, D. P. (1999): Can Global positioning system (GPS) improve trip reporting? Transportation Research Part C, 7(2-3): 149-165.

NOVÁK, J. (2010): Lokalizační data mobilních telefonů: možnosti využití v geografickém výzkumu. Dizertačná práca, Praha, Univerzita Karlova v Praze.

NOVÁK, J., SÝKORA, L. (2007): A city in motion: time-space activity and mobility patterns of suburban inhabitants and structuration of spatial organization in Prague Metropolitan Area. Geografiska Annaler B, 89(2): 147-168.

NOVÁK, J., TEMELOVÁ, J. (2012): Každodenní život a prostorová mobilita mladých Pražanů: pilotní studie využití lokalizačních dat mobilních telefonů. Sociologický časopis,. 48(5): 911-938.

OHMORI, N., NAKAZATO, M., SASAKI, K., NISHII, K., HARATA, N. (2006): Activity diary survey using GPS mobile phones and PDA. Transportation Research board $85^{\text {th }}$ Annual Meeting.

OSMAN, R. (2010): Specifika časoprostorového chování imobilních osob. In: Geografie pro život ve 21. století: Sborník příspěvků z XXII. sjezdu České geografické společnosti (pp. 478-482). Ostravská univerzita v Ostravě, Ostrava.

POSPÍŠILOVÁ, L., OUŘEDNÍČEK, M. (2011): Časoprostorové chování středoškolských studentů bydlících $\mathrm{v}$ zázemí Prahy. In: Vacková, B., Galčanová, L., Ferenčuhová, S. [eds.]: Třetí město (pp. 99-132). Červený Kostelec, Brno, Nakladatelství Pavel Mervart, Masarykova univerzita.

PRATT, A. C. (1996): Coordinating Employment, Transport and Housing in Cities: an Institutional Perspective. Urban Studies, 33(8): 1357-1375.

PRED, A. (1981): Social Reproduction and the TimeGeography of Everyday Life. Geografiska Annaler B: Human Geography, 63(1): 5-22.

RAPER, G., GARTNER, B., KARIMI, H., RIZOS, C. (2007): Applications of Location-Based Services: a Selected Review. Journal of Location Based Services, 1(2): 89-111.

RATTI, C., SEVTSUK, A., HUANG, S., PAILER, R. (2005): Mobile landscapes: Graz in real time. Proceedings of the $3^{\text {rd }}$ Symposium on LBS \& Telecartography, 28-30 November, Vienna, Austria.

RAUBAL, M., WINTER, S., TEßMANN, S., GAISBAUER, C. (2007): Time geography for ad-hoc shared-ride trip planning in mobile geosensor networks. ISPRS Journal of Photogrammetry and Remote Sensing, 62(5): 366-381.
RITSEMA VAN ECK, J., BURGHOUWT, G., DIJST, M. (2005): Lifestyles, spatial configurations and quality of life in daily travel: an explorative simulation study. Journal of Transport Geography, 13(2): 123-134.

SHAW, S.-L., YU, H., BOMBOM, L. S. (2008): A spacetime GIS approach to exploring large individualbased spatiotemporal datasets. Transactions in GIS, 12(4): 425-441.

SHAW, S.-L., WANG, D. (2000): Handling disaggregate spatiotemporal travel data in GIS. GeoInformatica, 4(2): 161-178.

SHOVAL, N., ISSACSON, M. (2006): Application of tracking technologies to the study of pedestrian spatial behavior. The Professional Geographer, 58(2): 172-183.

SPEK, S., SHAICK, J., BOIS, P., HAAN, R. (2009). Sensing human activity: GPS tracking. Sensors, 9(4): 3003-3055.

STOPHER, P. R., SHEN, L. (2011): An in-depth comparison of GPS and diary records. Paper Included in the Compendium for the 2011 Annual Meeting of the Transportation Research Board, Washington, DC. [online]. [cit. 15.04.2014] Available at: http:// assets.conferencespot.org/fileserver/file/32279/ filename $/ 12 \mathrm{kgd} 9 . \mathrm{pdf}$

TEMELOVÁ, J., NOVÁK, J. (2011): Daily street life in the inner city of Prague under transformation: the visual experience of socio-spatial differentiation and temporal rhythms. Visual Studies, 26(3): 213-228.

TEMELOVÁ, J., NOVÁK, J., POSPÍŠILOVÁ, L., DVOŘÁKOVÁ, N. (2011): Každodenní život, denní mobilita a adaptační strategie obyvatel $\mathrm{v}$ periferních lokalitách. Czech Sociological Review, 47(4): 831-858.

WEBER, J., KWAN, M.-P. (2002): Bringing time back in: a study on the influence of travel time variations and facility opening hours on individual accessibility. The Professional Geographer, 54(2): 226-240.

WOLF, J., BACHMAN, W., OLIVEIRA, M., AULD, .J., MOHAMMADIAN, A., VOVSHA, P. (2014): NCHRP report 775: Applying GPS data to understand travel behavior. Volume I: Background, methods, and tests. Washington, D. C., Transportation Research Board.

WOLF, J., OLIVIERA, M., THOMPSON, M. (2003): Impact of under-reporting on mileage and travel time estimates: results from global positioning system enhanced household travel survey. Transportation Research Record, 1854: 189-198.

YU, H., SHAW, S. L. (2008): Exploring potential human activities in physical and virtual spaces: a spatio-temporal GIS approach. International Journal of Geographical Information Science, 22(4): 409-430.

YUAN, Y., RAUBAL, M., LIU, Y. (2012): Correlating Mobile Phone Usage and Travel Behavior - A Case Study of Harbin, China. Computers, Environment and Urban Systems, 36(2): 118-130.

Initial submission 5 November 2014, final acceptance 23 April 2015

Please cite this article as:

ŠVEDA, M., MADAJOVÁ, M. (2015): Merging diaries and GPS records: The method of data collection for spatio-temporal research. Moravian Geographical Reports, 23(2): 12-25. DOI: 10.1515/mgr-2015-0007. 